\title{
INNOVATIVE APPROACHES \\ TO FORMULATION AND DEVELOPMENT \\ OF SOFT SKILLS OF SECONDARY SCHOOL STUDENTS IN THE CONTEXT OF UKRAINE'S \\ INTEGRATION INTO THE EUROPEAN EDUCATION AREA
}

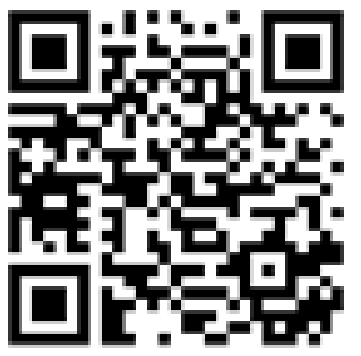

To cite this article:

\author{
Alina Dzhurylo, PhD \\ Senior Scientific Officer, \\ Comparative Education Department, Institute of Pedagogy, \\ National Academy of Educational Sciences of Ukraine \\ Kyiv, Ukraine \\ dzhurylo.ap@gmail.com \\ https://orcid.org/0000-0002-5129-6724
}

Oksana Hlushko, PhD

Scientific Officer,

Comparative Education Department, Institute of Pedagogy,

National Academy of Educational Sciences of Ukraine

Kyiv, Ukraine

glushko.oks74@gmail.com

https://orcid.org/0000-0003-0101-9910

Oksana Shparyk, PhD

Senior Scientific Officer,

Comparative Education Department, Institute of Pedagogy,

National Academy of Educational Sciences of Ukraine

Kyiv, Ukraine

shparyk.o@gmail.com

https://orcid.org/0000-0001-7507-4950

Dzhurylo, A., Hlushko, O., \& Shparyk, O. (2021). Innovative approaches to formulation and development of soft skills of secondary school students in the context of Ukraine's integration into the European education area. Education: Modern Discourses, (4), 39-49.

https://doi.org/10.37472/2617-3107-2021-4-05

Abstract. The paper is focused on the analysis of soft skills as basic competences for future professional success. During the study the concept of "soft skills" in the educational terminology of European countries and Ukraine was analysed; the importance of formation and developing soft skills for successful future professional development was justified; the directions of educational policy in EU countries and Ukraine to ensure the formation and development of soft skills of secondary school students were found out. As a result of research it was made the conclusion about the importance of soft skills formation and development in secondary school students 
for their future successful professional realization. It was offered the strategic directions on innovation approaches for the New Ukrainian School in formulation and development of soft skills at secondary school in the context of Ukrainian's integration into European and World education. In consequence of literature review it was determined that over one-third of skills (35\%) were considered important in that days' workforce would have changed over the next five years (the World Economic Forum, 2016). Today, employers look for job candidates who not only have professional skills in a particular field, but also understand how to make difficult decisions and demonstrate leadership skills. It is concluded that in an effort to prepare the younger generation for their future successful careers, educational institutions must ensure both the formation of professional skills ("hard skills") and the development of "soft skills", not limited to communication skills, because "soft skills" are also the ability to listen, work in a team, think critically, set goals and achieve them, the ability to resolve conflict situations, etc. "Hard skills" and "soft skills" in combination with motivation and personality form a pyramid of development of the future competitive professional. Career success depends on so much more than students' subject-matter knowledge and expertise. Based on the European experience the policy makers, educators and parents in Ukraine have been recommended to collaborate to ensure that each child's school experience fosters the social and personal skills that will ensure success when he or she enters the workforce.

Keywords: competences; European Education Area; future successful career; secondary school students; soft skills; workforce; Ukraine.

\section{INTRODUCTION, PROBLEM STATEMENT}

The level of professionalism will always be highly valued in any sphere of human activity, but in an extremely changing world with a hectic pace of life, educational institutions run the risk of imparting outdated knowledge to students before they graduate. Unlike hard skills, which are not only limited to a certain professional field, but also require constant upgrade, soft skills are super-professional skills that help solve life's problems and work with other people. Research conducted by Harvard University, the Carnegie Foundation and Stanford Research Centre has all concluded that $85 \%$ of job success comes from having well-developed soft and people skills, and only $15 \%$ of job success comes from technical skills and knowledge (hard skills). These statistics were extrapolated from A Study of Engineering Education, authored by Charles Riborg Mann and published in 1918 by the Carnegie Foundation (Mann, 1918). Scientists have known for almost 100 years that soft skills are critical to the success of any organization. The issue is what if soft skills are six times more important than hard skills for job success, why is almost $3 / 4$ of all the training spending going to hard skills?

In 2017 an internal survey was conducted by Google to determine the most productive teams within the company. The researchers found that their best were mixed groups of employees with strong flexible skills. Further research has shown that the success of the work was influenced by developed communication skills, empathy and leadership. Therefore, regardless of the chosen specialty, it is necessary to have at least some flexible skills to succeed in today's labour market. While academic learning is the foundation of education, a great school experience goes far beyond science fair projects and senior papers. More and more, educators are recognizing the importance of student's less quantifiable skills such as collaboration, self-discipline, and conflict resolution. These skills may be less easy to measure, but they are essential to a student's overall growth and development. Test scores and good grades might not present the whole picture of your child's education.

A report by Bloomberg reveals that while academic institutions focus on equipping students with the knowledge and hard skills for their future careers, businesses report that new 
hires are not prepared for success. The reason? Recent graduates lack the soft skills necessary for individuals to perform at a high level in the workplace. If recent graduates are not wellprepared for their new jobs, it is not because their hard skills are deficient. Some 90 percent of corporate respondents and 88 percent of academics surveyed said new recruits have the hard skills, such as computer literacy and written communication, to do their jobs successfully. But both groups, however, were far less satisfied with new employees' soft skills. Nearly four in 10 corporations and almost half of academic institutions said new hires lack the soft skills they need to perform at a high level (Bloomberg Next, 2018).

The survey respondents from both business and academia agreed the most important soft skills are:

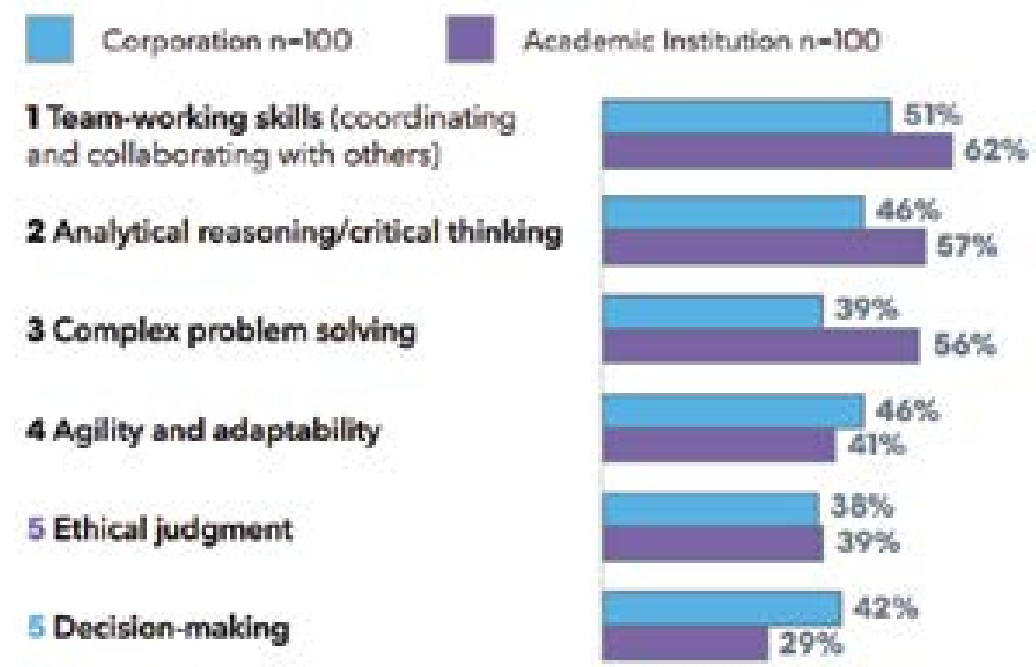

Fig. 1.

5 Most Important Soft Skills

Source: Bloomberg Next (2018). Building Tomorrow's Talent: Collaboration Can Close Emerging Skills Gap.

While hard skills are distinct and easy to measure (such as math and science), soft skills are less quantifiable. They include a variety of intra-personal and self-leadership skills such as collaboration, teamwork, time-management, and more. These "softer" skills enable an individual to adapt and succeed in the workplace. Great amount of international and national research reveals the importance employers place on soft skills. Teachers and parents must work together to ensure that each child's school experience fosters the social and personal skills that will ensure success when graduates enters the workforce.

Nowadays education is facing unprecedented challenges - social, economic and environmental - driven by accelerating globalization and a faster rate of technological developments. At the same time, those forces are providing us with myriad new opportunities for human advancement. The future is uncertain and we cannot predict it; but we need to be open and ready for it. The children entering education in 2022 will be young adults in 2035 . Schools can prepare them for jobs that have not yet been created, for technologies that have not yet been invented, to solve problems that have not yet been anticipated. It will be a shared responsibility to seize opportunities and find solutions. Future-ready students need to exercise agency, in their own education and throughout life.

OECD Education 2030 stakeholders have co-developed a "learning compass" that shows how young people can navigate their lives and their world (Figure 2). 


\section{The OECD Learning Framework 2030}
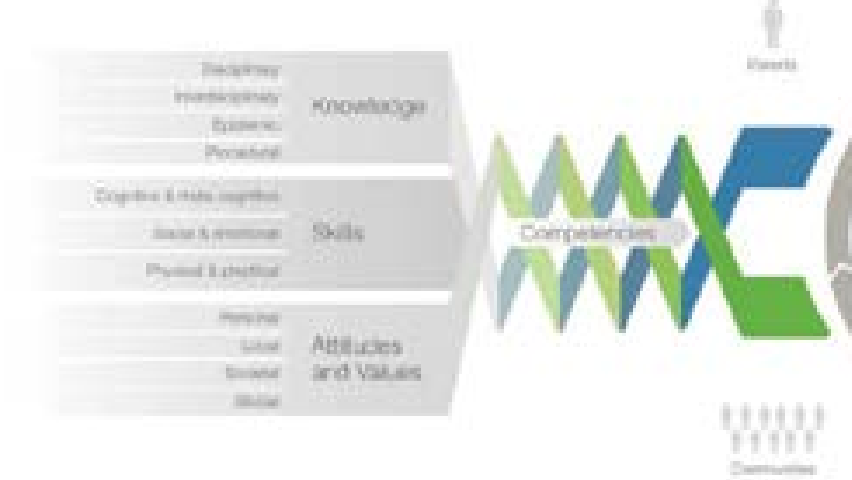

Fig. 2.

The OECD Learning Framework 2030: Work-in-progress

Source: OECD (2019). The Future of Education and Skills 2030.

The Figure 3 shows, the greatest difference between the level of education provided and the level needed for work is still in languages, IT, decision-making, leadership and management are also cross-disciplinary skills that show shortcomings when it comes to the labour market.

Theoretical skills
Practical skills
Documentation skalls
Written expression
Critical thought
Team work
Oral expression
Creativity
Problem-solving
Management
Leadership
Decision-making

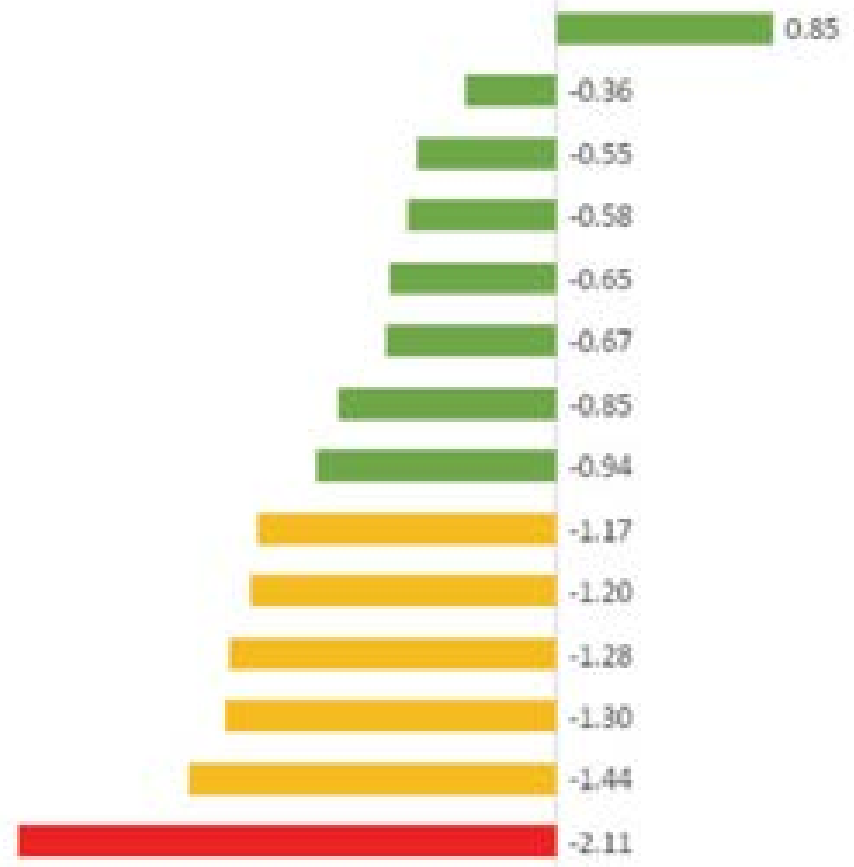

Fig. 3.

Education shortfall: difference between the assessment of the level of education provided in the study programme and its usefulness in work (only for graduates performing level-functions)

Source: Pérez, L. D. et al. (2020). National Reports on the Labour Market Soft-Skills Io1.A3. 
The aim of the paper is to analyse the concept of "soft skills" in the educational terminology of European countries and Ukraine; to justify the importance of formation and developing soft skills for successful future professional development; to find out the directions of educational policy in EU countries and Ukraine to ensure the formation and development of soft skills of secondary school students.

\section{LITERATURE REVIEW}

Research on the topic of soft skills is extremely relevant today, as evidenced by research and strategic documents of such international organizations as: United Nations (Sustainable Development Goals 2015-2030), OECD (Getting Skills Right: Skills for Jobs Indicators (2017); Skills Strategy Flanders Assessment and Recommendations (2019a); The Future of Education and Skills 2030 (2019)), European Commission (Education and Training: Monitoring (2020); The European Higher Education Area in 2020: Bologna Process Implementation Report (2020a)), CEDEFOP (Skills Forecasting. Trends and Challenges until 2030 (2018)), World Economic Forum (The Future of Jobs Employment, Skills and Workforce Strategy for the Fourth Industrial Revolution (2016)). All these studies are united by a common opinion - educational institution on all level ought to teach, develop and improve students' uniquely human capacity for creativity, communication, responsibility, emotional intelligence, empathy and the ability to learn throughout their life.

As part of the Erasmus+ Program the study titled "National reports on the labour market soft-skills IO1.A3" (Perez, et al., 2020) was conducted by the group of researchers to analyse the situation regarding the acquisition and application of soft-skills in EU countries (Belgium, Italy, Lithuania, Romania, Spain), to evaluate the reaction of employers for the soft-skills of the labour force and to assess how the educational institutions respond to the need of labour market regarding the soft-skills strengthening.

A substantial contribution to the formation of the idea of competence-oriented education in the Ukrainian educational space was made by N. Bibik, O. Lokshyna, O. Ovcharuk, L. Parashchenko, O. Pometun, O. Savchenko, S. Trubecheva (Lokshyna, 2014).

The Ukrainian comparative education scholars also contribute to the development of the competence education in Ukraine. O. Lokshyna (2019) noted the importance of the European Reference Framework of Key Competencies for Lifelong Learning for the development of education in Ukraine. The author characterized the innovations of the updated version of the Framework based on a comparison of the European Reference Framework of Key Competencies for Lifelong Learning of 2006 and 2018. Based on the comparison of the list of key competences of the 2006 and 2018 European Frameworks with the key competences adopted by the Law of Ukraine "On Education (2017) the author concluded that the list of the Ukrainian education key competencies needs to be constantly updated in the face of rapidly changing challenges (Lokshyna, 2019).

The competence approach in the secondary education of the EU countries was analysed by O. Hlushko (2021). Important for the Ukrainian education is the author's conclusion that the introduction of key competencies in school education takes place through different approaches and depends on the national visions/possibilities of the EU Member States (Hlushko, 2021).

O. Shparyk (2021) outlined the views of the European and American researchers on the theoretical framework of the digital transformation of education. As IT is one of crossdisciplinary skills that show shortcomings when it comes to the labour market, the author concluded that the use of digital technologies is a mechanism for ensuring efficiency and increasing productivity in the educational process, and the digital transformation of education appears as a key factor in improving the education system (Shparyk, 2021). 


\section{METHODOLOGY}

In the research paper a qualitative approach is used. By using the qualitative approach the researchers are expected to solve problems as expected. This type of research is a case study, which is a study directed at collecting data, taking meaning, gaining an understanding of a case. To complete the tasks of the study a complex of research methodologies and research methods was used, namely: the method of terminological analysis (to investigate of the soft skills concept), the method of comparative analysis (to compare the practice of developing soft skills in the leading EU countries and in Ukraine).

\section{MAIN RESULTS}

For the successful development of a competitive Europe, its innovative potential, the creation of a knowledge society as defined by the Sustainable Europe 2030 it is necessary to have highly educated and well trained workers. The training of qualified personnel within the needs of the current labour market is one of the components and key to the successful development of a state. Formation of skills of the $21^{\text {st }}$ century starts at school and lasts for a lifetime (Dzhurylo, Shparyk, 2019).

There are a lot of ways to name soft skills, also called social skills, transversal competences, social competences, generic competences, even basic and life skills. Some international research projects or institutions prefer the term " $21^{\text {st }}$ century skills", whereas the Organisation for Economic Cooperation and Development uses the terms "key competencies" (OECD, 2003) and more recently, "skills for social progress" (OECD, 2015).

In Europe different countries use different denominations: Austria gr. "Schlüsselkompetenzen" (key competencies); Belgium - fr. "compétences transversals" (transversal competencies), nl. "Sleutelcompetenties" (key competencies); Denmark dn. "Nøglekompetence" (key competencies); England - eng. key skills (England, Ireland), eng. core skills (Scotland), eng. life skills, key transferable skills, cross competencies; France fr. "compétences transversals" (transversal competencies); Germany - gr. "Schlüsselkompetenzen" (key competencies), gr. "übergreifende Kompetenzen" (general competencies); Italy ita. "competenzetrasversali" (transversal competencies); Portugal-por. "competênciasessencias" (essential competencies), por. "competências transversais ou genéricas" (transversal or generic competencies); Spain - spa. "competencias genéricas" (generic competencies) (Cinque, 2016).

Some authors identify soft skills with emotional intelligence or emotional quotient, i.e. the "emotional side" of human beings in opposition to the intelligent quotient. One might debate if soft skills like "critical thinking" or "problem solving" might be considered emotional skills. Some authors call them "non cognitive skills" but, as a matter of fact, soft skills include both social/interpersonal skills and methodological skills or meta-competences, i.e. the capacity to work on competences, to reframe and transfer them from one field to another, even from informal to formal learning. Soft skills must also be conceptualized in a broad sense, as competences transferable from job to job, from company to company, from one economic sector to another. Soft skills could be defined as "wicked competences," as it is very difficult to define them, because they can assume different forms in different contexts and they keep developing along the entire lifetime (Cinque, 2016). So obviously the question of defining the concept of soft skills is still open. In the terminology of different countries, this concept is defined differently and includes a set of different qualities and characteristics.

In Europe at a national level, the state of the art on soft skills varies from country to country. While in some countries the topic seems to be very important - and therefore it is easier to find research on it, in other countries this topic is still developing. 
French schools are very academic in their way of teaching: they focus on hard skills such as reading, counting, learning dates, facts and so on. French parents tend to think that children go to school to learn such skills, to gain knowledge which can be measured, tested. Even though the importance of teaching soft skills is becoming more recognized in France, the methods used to achieve this goal are still very academic: to teach the children to be good citizens, they are taught historic dates and facts, symbols of the republic and such things, which they have to learn by heart. The nowadays aim for French school is to find better ways to teach young students these essential skills: respect, solidarity, team working and so on.

In Greece, there is a general recognition of the importance of soft skills in improving the productivity of the workforce, but there is still quite a degree of ambiguity in defining their boundaries. In general, soft skills are seen as people-oriented skills and self-management skills. At a national level there are not many initiatives that are dedicated to this problem and most of them are associated with European policy and European funds, like in the case of Poland. The importance of soft skills for enhancing employability, personal fulfilment and social participation is widely accepted. In Greece, the educational institutions have accepted that they should prepare their students for a complex and uncertain society and labour market. While they appear to have accepted their new vocational role, there is considerable confusion over how generic competencies, soft skills, attributes or capabilities should be defined and implemented.

In Germany, the topic is considered very relevant and the focus is more on "key skills" that, as we have seen previously, only partially overlap the concept of soft skills. There are many initiatives that stress the importance of key skills and that promote recommendations on how to organize and implement skills in education.

Soft skills and digital skills are also very important in Spain, as it is reflected by the debates and amount of research on this issue recently. There is a lot of research coming from Spanish universities, which has treated the topic of how to introduce soft skills in the academic curriculums. However, according to some sources, it is believed that these actions have been taken without having generated enough debate on the issue in order to clarify the concepts around it and to analyse the most appropriate models. The initiatives are not only appearing in the academic context, but also in companies, where there are trainings on soft skills.

In independent Ukraine, secondary education development is featured by dynamics and correlation with the tendencies of the school education development in foreign countries, in particularly, in the European states; this process is influenced by such common challenges as globalization, active soft skills development, ICT implementation, reinforcement of the cultural interpenetration. For the purpose of these challenges resistance, the countries are focused on the large-scale governmental, organizational, and content transformations. Significant theoretical lay-outs of European scholars as well as their expertise which has been gained in this area are valuable for the further evolvement of the Ukrainian secondary education in the process of European integration (Lokshyna, Shparyk \& Dzhurylo, 2015).

In Ukrainian it is used concept "soft skills" borrowed from English which means universal competencies, immeasurable skills such as sociability, teamwork, time management, creativity etc.; it may be also called personal qualities depended on a person's character such as social, intellectual and volitional competencies (sociability, punctuality, balance).

The importance of soft skills for students any ages is enormous, both with regard to their studies and with regard to their future careers. Students who recognize the importance of soft skills on time are able to master their studies more successfully, complete their student obligations smoothly, make more acquaintances that may prove useful in the future, and better present themselves to professors who can also play an important role in their future careers. Soft skills are in direct correlation with improved academic achievement, so students should develop them for the sake of their education. 
Students are individuals who will join the ranks of academic citizens after graduation, so it is very important that they develop desirable and appropriate forms of behaviour, traits and skills to match their social and educational status. As such, they should be an example of well-developed and balanced individuals with virtues and qualities expected from individuals with their education.

Standards writers, curriculum designers, and classroom teachers all over the world have spent the past several years clamouring to find ways to revitalize curriculum and instruction and increase rigor in ways that prepare students for life after school.

People develop soft skills through socialization, learning the values, attitudes, and actions through interactions with others. Because socialization and relationship-building are a critical part of young adolescents' lives, school is a perfect place to incorporate soft skill development into the school day. By adding this important element to instructional plans and classroom expectations, educators help prepare students for success after graduation.

In independent Ukraine, secondary education development is featured by dynamics and correlation with the tendencies of the school education development in foreign countries, in particularly, in the European states; this process is influenced by such common challenges as globalization, active soft skills development, ICT implementation, reinforcement of the cultural interpenetration. For the purpose of these challenges resistance, the countries are focused on the large-scale governmental, organizational, and content transformations. Significant theoretical lay-outs of European scholars as well as their expertise which has been gained in this area are valuable for the further evolvement of the Ukrainian secondary education in the process of European integration. In November 2019, the Ministry of Education and Science of Ukraine issued an order to conduct an all-Ukrainian experiment on "Organizational and pedagogical conditions for developing soft skills in students through socio-emotional and ethical learning" on the basis of secondary education for November 2019 - December 2024. Within 5 years, 26 schools from different regions of the country will implement a system for the development of soft skills, socio-emotional and ethical learning (SEEN or SEE Learning). Former Minister of Education and Science H. Novosad supposed in support of the project that soft skills are an integral part of successful learning and a mandatory competence that a graduate of the New Ukrainian School should have. After all, to accumulate knowledge in subjects today is not enough to realize their skills and become successful. It is also important to understand that "soft skills" is a broad concept that involves the ability to solve complex problems, think creatively and critically, communicate and collaborate. Such skills need to be linked to all subjects currently taught in Ukrainian schools. In addition, as SEEN is a flexible and inclusive program, it is necessary to fill it with the best Ukrainian practices, taking into account national specifics (Ministry of Education and Science, 2019).

The Social Emotional and Ethical (SEE) Learning program is a tool for developing soft skills. Such as the ability to communicate, empathize with yourself and others, manage your emotions, work in a team, think creatively and critically, lead and follow leaders thoughtfully, and so on. Such learning develops students' awareness, empathy and involvement.

SEEN is an educational program developed by Emory University specialists for international use. Each level of education has its own sets of lessons: for early primary school (1-2 grades), for late primary school (3-4 grades), for secondary (5-9 grades), for senior (1012 grades), while there are only in the draft version.

The programme already operates in the United States, Chile, Colombia, Brazil, Austria, Germany, Switzerland, Spain, Italy and India. He immediately created it as one that suits different cultures. Scientists have tested SEEN, taking into account the specifics of different countries.

Awareness, empathy and involvement are the three key skills that are developed within 
the programme. They are revealed at three levels of involvement: personal (I), social (I - in class, family, with friends) and systemic (I - in the country, system, on the continent, on the planet). As a result, an understanding of interdependence is formed (Markovska, 2020).

SEE Learning Programme for the New Ukrainian School has four key learning trajectories. They outline ways to study, critically evaluate and master a variety of topics and skills. The first trajectory is critical thinking: encouraging children to make their own arguments, to take an active part in reasoning, to study the process by finding the right questions, discussions, dialogues, and not to focus on ready-made solutions. The next trajectory is reflective practices: activities in which students focus on their inner experiences. Students try to pass the learning material through themselves through attention, contemplation and reflective observations. The third trajectory is the scientific perspective: As socio-emotional learning considers ethical development through emotional literacy education, it is important that children and teachers have a scientific basis for understanding emotions and other topics in the program. Topics in biology, psychology and neurobiology (such as emotions related to the cerebral cortex, etc.) are useful for studying materials. The final trajectory is active learning: these are strategies and methods that involve the active participation of students in learning the material. These can be group learning (group projects, discussions, joint games), creative expression through music, writing, community involvement projects and environmental learning (planting trees).

Innovative approaches to formulation and development of soft skills at secondary school in the context of Ukrainian's integration into European and world education area might be the following:

- Lessons with experiments with further discussion of the topic.

- Education through creativity and international holidays.

- Involvement of foreign teachers, volunteers (in particular - foreign students of a higher education institution for an online or offline meeting with the class).

- Social work (visiting animal shelters, geriatric boarding houses; such measures promote tolerance towards others, the expert notes).

- Vacation camps and trips abroad.

- Exchange training.

- Volunteering (visiting orphanages, orphanages, helping the elderly etc.).

- Robotics.

- Digital storytelling (used to tell different technologies: texts, videos, audio, interactivity).

The New Ukrainian School should not just pass on knowledge, but learn to apply it in practice, develop soft skills and cross-cutting skills such as teamwork, developed emotional intelligence and empathy, critical thinking. Children should not be afraid to ask questions, find and evaluate information on their own. These end-to-end skills are needed by anyone to be successful in today's world.

\section{CONLUSIONS}

The main goal of the reform of general secondary education in Ukraine is to create a school that will be pleasant to study and that will give students not only knowledge of how it is happening now, but also the ability to apply them in everyday life. The New Ukrainian School should become a school that students enjoy, which not only provides thorough knowledge, but also develops the soft skills necessary for life. For the successful realization of this goal it is necessary to abandon the approach "teacher dictates - student writes". Passive learning style should give way to active - visual and interactive. New technologies should become the main tools for teachers. 
European belonging of Ukraine, its geographical and mental closeness to the EU, devotion to the European values, contributes to the Europeanization of Ukraine and the Europeanization of the Ukrainian education in particular. Europeanization serves as an imperative for the further development of the state policy in the direction of competence approach, informatisation, transformation of education into a digital based one along the EU lines (Lokshyna, Glushko \& Tymenko, 2018; Topuzov, 2015).

The continuous development of new technologies already forces people to constantly work on themselves: to improve, master additional skills and change professions. Accordingly, a teacher cannot stay away, because the quality of his or her work and the results of his or her students depend on how quickly he or she learns and applies soft skills, switches to new methods and experiments.

By the 2040 s, robotics will absorb almost $50 \%$ of modern professions. The machines are expected to lose not only couriers and cleaners, but also white-collar mortgage brokers, lawyers and accountants. Probably, some lecturers and tutors will be replaced by chat bots. However, specialists who have competencies inaccessible to robots are not threatened by automation. Therefore, it is important to develop critical thinking, creativity, ability to communicate, work in a team. The most important competence that will be the advantage of people over work is empathy. The modern teacher should not compete with Google. Students should be given a tool with which they will build their own educational route, reveal their potential. Robotization will require from the teacher the skills of "four C", without which it is difficult to imagine a specialist of the future: communication, creativity, critical thinking and collaboration.

In the near future, the need for lifelong learning will become even more acute. Scientists from the World Health Organization and Imperial College London have predicted that by 2030 , scientists will find a way to extend life expectancy to 120 years. People will retire after celebrating their $100^{\text {th }}$ anniversary. For teachers this means to set themselves and their students up for lifelong learning now.

A teacher of the New Ukrainian School is to become a leader - a role model for students, and teacher's main task - to help students find their purpose, consciously choose a future profession and reveal leadership qualities. Therefore, new goals require new teaching methods.

\section{REFERENCES}

Bloomberg Next. (2018). Building Tomorrow's Talent: Collaboration Can Close Emerging Skills Gap. Retrieved 2021 from: http://unitedwayswva.org/wp-content/uploads/2019/07/BuildingTomorrows-Talent-Collaboration-Can-Close-Emerging-Skills-Gap.pdf

Cedefop, Eurofound. (2019). Skills forecast: trends and challenges to 2030. Publications Office. http://data.europa.eu/doi/10.2801/4492

Cinque, M. (2016). "Lost in translation". Soft skills development in European countries. Tuning Journal for Higher Education, 3(2),389-427.https://doi.org/10.18543/tjhe-3(2)-2016pp389-42

Dzhurylo, A. P., Shparyk, O. M. (2019). ICT Competence for Secondary School Teachers and Students in the Context of Education Informatization: Global Experience and Challenges for Ukraine. Information Technologies and Learning Tools, Vol 70, №2, 43-58. https://doi.org/10.33407/itlt.v70i2.2438

European Commission. (2020). Education and Training Monitor 2020: Teaching and learning in a digital age. Publications Office. https://data.europa.eu/doi/10.2766/759166

European Commission. (2020a). The European Higher Education Area in 2020: Bologna Process Implementation Report. Publications Office of the European Union. http://data.europa.eu/ eli/dec/2011/833/oj

Hlushko, O. (2021). Kompetentnisnyi pidkhid v osviti: yevropeiskyi dosvid. Naukovo-pedahohichni studii, 5, 8-21. https://doi.org/10.32405/2663-5739-2021-5-8-21

Lokshyna, O. I. (2014). "Kompetentnisna” ideia v osviti zarubizhzhia: uspikhy ta problemy realizatsii. Kompetentnisnyi pidkhid v osviti: teoretychni zasady i praktyka realizatsii, 1, 51-59. https://core.ac.uk/download/pdf/32307202.pdf 
Lokshyna, O., Shparyk, O. \& Dzhurylo, A. (2015). The European Vector of School Education Content Transformations in Ukraine. Science and Education a New Dimension. Pedagogy and Psychology, III (30), Issue: 59. Retrieved 2021 from: http://seanewdim.com/ uploads/3/4/5/1/34511564/ped_psy_iii30_59.pdf

Lokshyna, O., Glushko, O. \& Tymenko, M. (2018). Informatisation of School Education in Ukraine under Globalization and Europeanization. ICT in Education, Research and Industrial Applications: $14^{\text {th }}$ Int. Conference, ICTERI 2018. Volume I: Main Conference. Kyiv, May 14-17, 302-316. Retrieved 2021 from: http://ceur-ws.org/Vol-2105/10000302.pdf

Lokshyna, O. I. (2019). Yevropeiska dovidkova ramka kliuchovykh kompetentnostei dlia navchannia vprodovzh zhyttia: onovlene bachennia 2018 roku. Ukrainskyi pedahohichnyi zhurnal, 3, 21-30. https://doi.org/10.32405/2411-1317-2019-3-21-30

Mann, Charles Riborg. (1918). A Study of Engineering Education. Prepared for the Joint Committee on Engineering Education of the National Engineering Societies. Bulletin Number Eleven. D. B. Updike, The Merrymount Press. Retrieved 2021 from:

https://www.nationalsoftskills.org/downloads/Mann-1918-Study_of_Engineering_Educ.pdf

Markovska, Maria (2020). Shcho take prohrama sotsialno-emotsiinoho ta etychnoho navchannia $i$ yak vona pratsiuie. Retrieved 2021 from: https://nus.org.ua/articles/shho-take-programasotsialno-emotsijnogo-ta-etychnogo-navchannya-i-yak-vona-pratsyuye/

Ministry of Education and Science of Ukraine (2019). Do 2024 roku $v 26$ ukrainskykh shkolakh pilotuvatymut proiekt $z$ rozvytku miakykh navychok - nakaz MON. Retrieved 2021 from: https://mon.gov.ua/ua/news/do-2024-roku-v-26-ukrayinskih-shkolah-pilotuvatimutproyekt-z-rozvitku-myakih-navichok-nakaz-mon

OECD. (2003). Definition and Selection of Competencies: Theoretical and Conceptual Foundations. Summary of the final report Key Competencies for a Successful Life and a Well-functioning Society. OECD Publishing. https://www.oecd.org/pisa/35070367.pdf

OECD. (2015). Skills for Social Progress: The Power of Social and Emotional Skills. OECD Skills Studies. OECD Publishing. https://doi.org/10.1787/9789264226159-en

OECD. (2017). Getting Skills Right: Skills for Jobs Indicators. Getting Skills Right. OECD Publishing, Paris. https://doi.org/10.1787/9789264277878-en.

OECD. (2019). The Future of Education and Skills 2030. OECD Publishing. http://www.oecd.org/ education/2030/oecd-education-2030-position-paper.pdf

OECD. (2019a). OECD Skills Strategy Flanders: Assessment and Recommendations. OECD Skills Studies. OECD Publishing. https://doi.org/10.1787/9789264309791-en.

Pérez, L. D. et al. (2020). National Reports on the Labour Market Soft-Skills Io1.A3. Retrieved 2021 from: https://skills4employability.eu/wp-content/uploads/2020/08/National-Reports-onSoft-Skills-current-scenarios-by-Skills4Empolyability-Erasmus-Project-IO1.A3-.pdf

Shparyk, O. (2021). Kontseptualni zasady tsyfrovoi transformatsii osvity: yevropeiskyi ta amerykanskyi dyskurs. Ukrainskyi pedahohichnyi zhurnal, 4, 65-76. https://doi. org/10.32405/2411-1317-2021-4-65-76

Topuzov, O. M. (2012). Rol i mistse pidruchnyka v realizatsii kompetentnisnoho pidkhodu do navchannia [The role and place of the textbook in the implementation of the competence approach to learning]. Problemy suchasnoho pidruchnyka, 12, 241-247.

Topuzov, O. M. (2015). Zabezpechennia yakosti zahalnoi serednoi osvity: na shliakhu do yevropeiskykh standartiv [The guarantee of the quality of the comprehensive secondary education: on the way to the European standards]. Ukrainskyi pedahohichnyi zhurnal, 1, $16-27$.

UNDP. (2015). Sustainable Development Goals. https://www.ua.undp.org/content/ukraine/en/ home/sustainable-development-goals.html

World Economic Forum. (2016). The Future of Jobs. Employment, Skills and Workforce Strategy for the Fourth Industrial Revolution. Global Challenge Insight Report. https://www3.weforum. org/docs/WEF_Future_of_Jobs.pdf 